\title{
Microfilm for the Library of Congress
}

\begin{abstract}
In 1969 alone, the Library of Congress produced more than 11.3 million individual microfilm exposures on negative film. More than 5.6 million feet of positive print film were made from these and other negatives. Microfilming has been used to solve the need for storage space; to preserve newspapers and rare and fragile documents; to produce copies for outside orders; to conserve copyright records; and to acquire new materials for the Library collections.
\end{abstract}

F cBRss, the Library of Congress has grown from a few hundred volumes to more than 13 million books and pamphlets, more than 19 million manuscripts, 165,000 bound volumes of newspapers, and many other materials. It has used microfilm to preserve public records since 1938, when its Photoduplication Service was established with a revolving fund grant from the Rockefeller Foundation.

Many information storage and retrieval techniques now common in the library sciences were initiated here to protect historical documents and also to provide quick access to researchers. Microfilm also has been invaluable as a recording tool, duplicating rare manuscripts and documents that otherwise would have been unavailable. It also is used to preserve deteriorating materials and for the acquisition of new collections. The Photoduplication Service now has 163 employees, with 78 of them working in microfilming operations.

One of the largest of our microfilm-

Charles G. La Hood, Jr. is chief, Photoduplication Service, Library of Congress. ing projects is the preservation of newspaper records, begun in 1939 with the microfilming of The Washington Post, The Washington Star, and The National Intelligencer on $35 \mathrm{~mm}$ roll microfilm. The program was extended in 1962 to the filming of newspaper volumes dating back to 1870 , when sulfide paper was first used for newsprint.

As early as 1901, Allan B. Slausen, then chief of the Library of Congress Periodical Division, noted in his annual report to the Librarian of Congress:

Wood pulp paper, upon which newspapers are now printed, disintegrates after a few years, when exposed to the light, and edges of bound volumes near the windows already begin to show that extra precautions must be taken if the files of newspapers are to last beyond one or at the most two decades.

Slausen made suggestions for preserving newspaper files, but microfilming, of course, was not even dreamed of at that point.

Microfilming came at a propitious time, as the Library of Congress was experiencing an acute space problem in its newspaper collection. By 1949, just 
one decade after the bound newspaper collection had been moved to the $\mathrm{Li}$ brary Annex, the collection already had become so extensive, comprising over 140,000 volumes, that all available shelf space-approximately eighteen linear miles-was filled. With no other shelf space available, the stack area floor space was used for storage. With the collection growing at the rate of 3,000 bound volumes per year, there was a critical need for microfilm to mitigate the space problem, as well as to maintain long-range preservation requirements.

By 1951, the Library had acquired 21,000 reels of positive microfilm from outside sources and from negatives filmed by photoreproduction. At this time, the library had 88 newspaper subscriptions for microfilm-56 domestic and 32 foreign titles. Newspaper titles received by the Library, however, exceeded 1,000. By 1961, although the Library subscribed to every available microfilm of newspapers it wished to retain permanently, these accounted only for half the 1,200 domestic and foreign titles normally retained. The remaining 600 titles were bound for storage.

In 1962, current and past newspaper files were transferred to microfilm. Of the 165,000 bound volumes of newspapers on file, approximately 25,000 were printed after 1870 on pulp paper. Many were in advanced stages of deterioration. With time running out on many of these files, the goal of replacing all pulp paper with microfilm meant that all 125,000 volumes, averaging three inches in thickness-a total of 75 million pages-had to be committed to positive microfilm from negatives already in existence and available from outside sources, or negatives to be produced by photoduplication.

When a negative microfilm is available, the Library acquires only a positive print, after a cautious quality-control procedure. Existing negatives often are of uneven quality-usually due to exposure of tightly-bound newspapers resulting in incomplete images, or simply poor microfilming techniques. Normally, the Library requires the supplier to furnish sample rolls of each file for quality-control testing before ordering, so that the pulp files are not destroyed prematurely. Since 1962, 25,000 bound volumes have been replaced by microfilm positives. At this writing, we have reached the approximate half-way point in the replacement program-50,000 volumes on film.

Some problems in microfilming historical newspaper files are missing issues in a bound volume, as well as the human errors made in cataloging the original files. Each volume must be checked for the shelflist record of missing pages and/or issues, and for proper indexing. Any material missing from the file must then be secured. The volume is sent to the Government Printing Office bindery, where bindings are cut from the newsprint, reducing the volume to a stack of loose pages held between the binding covers. Wrinkled or creased papers are sprayed with a fine water mist, stacked in a bookbinding press between sheets of plywood and placed under pressure for twenty-four hours. Any remaining creases or wrinkles are removed with a hand iron on the camera table. Highresolution planetary cameras, of which the Library has 24 , are used to document the newspapers onto microfilm. All cameras are tested monthly with resolution test charts and with periodic step tests to check proper light intensity levels. In addition, the lighting at various points in the copy plane is checked frequently and adjusted to provide even illumination of the image area. If one light bulb burns out, all are replaced to achieve more readily-balanced lighting.

Negative microfilm exposed in the cameras is processed automatically in a custom-built machine capable of handling 100 feet of film a minute. After 
processing, the 1,000-foot rolls of film are broken into individual orders and reels by an inspector who simultaneously makes a pre-editing check for scratched film, blurred images due to page movement, and camera troubles. This check allows correction to be made in cameras or processing as quickly as possible, minimizing the damage donea necessary precaution when 7,000 feet of negative film is produced each day.

Negative film passing the first inspection is assigned to an editor who makes a frame-by-frame inspection to see that all pages were filmed and in proper order, the film images are properly aligned, the proper targets were used, and that each image is in focus, properly lighted, and has good contrast. The background density of each frame is checked by eye, and an electronic densitometer is used to make a spot check every few feet along the film.

Editing is done at specially-designed consoles with built-in light panels, rewinds, and specially-mounted heat-weld splicers. Loupes used to check negative film are padded to prevent film scratching. Film readers also inspect newspaper microfilm. Each reader is equipped with glass flats that are pushed away from the film manually before the film is advanced, giving positive protection against scratching.

In the Library of Congress system, the original negative microfilm is used to make an intermediate negative print, from which release positive prints are made. The original negative is placed in permanent storage. In this process, the negative film is checked for variations in density. If a variation is noted, a notch is made in the edge of the film twelve inches before the variation occurs. The light values corresponding to the changes in density in the film are recorded on a light strip that is used to set resistor bars on the control board of the printer.

When the printer is operated, each notch in the film negative activates another switch that varies the intensity of the light source in accordance with the values preset into the control panel. Variations in density in the negative are thus eliminated in printing, and the resulting intermediate negative print is of even better quality than the original negative. The light strip for each negative roll is retained with the reel, so that if an additional intermediate print is required, it, too, can be corrected automatically.

From the intermediate film, positive prints are made for the library's reading rooms or for distribution to subscribers. The positives are checked after processing for printing or processing errors and spooled for storage.

Completing the newspaper microfilming operation, the master negatives are stored in the negative vault, where they are inspected frequently to ensure against damage. Then, and only then, are the subject newspaper files cleared for disposal.

The microfilming of newspaper files has many advantages for the library and its users. Not only are the pages of newsprint captured permanently on film, but the space required to house the printed volumes is reduced drastically. And, from the user's viewpoint, a small reel of microfilm is much easier to handle and use than a fifteen-to-twentypound, three-inch thick, bound volume of print.

The microfilm preservation program is not limited to newspapers. Irreplaceable reference works and other materials in a deteriorating condition are being microfilmed and then reproduced, either on full-size electrostatic prints or on positive microfilm. Presidential papers-from Washington to Coolidgeare microfilmed to insure preservation, and also to make positive reproductions readily available without additional handling of the original document and the consequent possibility of damage. 
Since 1962, rare monographs have been put on microfilm, at the rate of 5,000 a year. Of the 13 million books in the library, at least 2 million have become brittle and fragile with age. A number of the microfilm cameras are equipped with a special book cradle to allow page-by-page filming. Once filmed, the book is withheld from the stacks and reference is made via a microfilm positive.

Acquisition of library material is as important an application of our microfilming equipment as is the preservation program. Recently, for example, a fine collection of material at St. Catherine's Monastery on Mount Sinai was added via 1,694 reels of microfilm shot on the site. At the same time, we added 1,000 reels of microfilmed materials on Jerusalem.

Microfilm also has become a favorite way for the library to acquire rare materials. The early records of the stateslegislative records, statutory laws, court records, constitutional records, for example-are scattered throughout the land. Desiring this material for the Library of Congress, the only recourse was to travel to the various state capitals and microfilm the documents and manuscripts. This was done, using a total 120,000 feet of microfilm, making this data available to library users.
As our files of microfilm grow, they are playing an increasingly important role in what has become the largest library copy service in the country. Any material in the library can be reproduced-unless covered by a copyrighteither photostatically, or by producing positive paper copies or positive film copies of microfilm. In 1969 alone, 88,000 requests covering 172,000 different items to be copied were received.

Peripheral uses of microfilm at the Library of Congress include retention of library catalog cards and Copyright Office records. The Copyright Office has nineteen different application forms, submitted by authors, composers, and publishers, which the office microfilms along with the original document to insure against loss. In addition, the copyright card catalog containing records of the more than 11 million works that have been copyrighted-the list is expanded by about 300,000 items a yearis retained on microfilm.

Microfilm is the Library of Congress' best protection against loss of original materials and valuable documents. Never again will the Library of Congress be wiped out of existence, as it was during the War of 1812 , when the 3,000 volumes that constituted the entire Library were burned, along with the rest of Washington. 